\title{
Influence of the complex of vitamins Pikovit in culture in vitro on the growth and development of potato microplants
}

\author{
Yulia Fedorova*, Larisa Fedorova, and Margarita Zaitseva \\ Federal State-Owned Publicly-Funded Institution of Higher Education Velikie Luki State Agricultural \\ Academy, 182112 Russia, Pskov Region, Velikie Luki, 2 Lenina Prospekt
}

\begin{abstract}
In the conditions of the North-West zone of Russia, studies of Pikovit vitamin complex preparation were carried out. Since the main way to obtain a healthy seed is clonal micropropagation. Therefore, in the course of the work, the process and method of clonal micropropagation of Russian potato varieties using new preparations were improved, the selection of nutrient media at all stages of cultivation was carried out with the Pikovit preparation at the concentration of 0.5 to $1.5 \mathrm{mg} / \mathrm{l}$. As a result, it was found that use of the Pikovit vitamin complex has a positive effect on the ontogenesis of potato microplants. To obtain well-developed microplants of the early variety Liga, the most optimal concentration is $1.5 \mathrm{mg} / 1$. For other studied varieties of the mid-ripening group Aurora and Gusar, the nutrient medium with the addition of vitamins at the concentration of $1.0 \mathrm{mg} / \mathrm{l}$ was optimal.
\end{abstract}

\section{Introduction}

One of the main agricultural crops is potato, its demand among the population is increasing every year. In our country about 3 million hectares of arable land are occupied by potatoes. The potential of modern potato varieties is up to $80 \mathrm{t} / \mathrm{ha}$ and more, but, unfortunately, in most farms, the yield of this crop does not exceed $20 \mathrm{t} / \mathrm{ha}$. This is primarily due to the low quality of the used seed [1].

Seed potato growers understand that large-scale production of healthy seed is not possible without the widespread use of the latest developments in agricultural biotechnology. [7].

Seeding potatoes is a complex, energy-consuming and labor-intensive process. In the context of a lack of production of domestic seed potatoes, one of the main ways to increase the volume of cultivation of the original healthy seed material is development of new methods for intensifying the process of reproduction of seed potato seed at the initial stages of seed production [16].

Within potato seed production, the most important thing is to obtain high, high-quality and sustainable yields. One of the main ways to increase production of volumes of

\footnotetext{
*Corresponding author: nauka@vgsa.ru
} 
cultivating the original revitalized seed material at the very first stages of seed production is development of new methods for intensifying the process of potato reproduction [5].

The main solution to the process of reproduction of the original potato is to obtain the source material free from viral and bacterial infections. Today, our modern potato growers understand very well that large-scale production of healthy seed material is impossible without the widespread use of the latest developments in the field of agricultural biotechnology $[4,13]$.

The methods of modern biotechnology make it possible to carry out work on production of elite potato planting material all year round. In order to achieve positive results in carrying out these works, a detailed selection of conditions for plant cultivation in vitro is required. There is also the study of nutrient media and its individual components, which will ensure the optimal development of plants and their productivity in the future. Since, potatoes are very demanding for provision of nutrients [9].

Accelerated micropropagation is carried out using cuttings. Placing the explant in the form of a micro-cut on a new nutrient medium promotes cell differentiation and formation of new organs. Growth of the stem and roots begins 3-4 days after planting, the composition of the nutrient medium affects the organogenesis and the multiplication factor of the studied potato varieties. Improving the reproduction technology of the source material is aimed at selecting the optimal concentration of the Pikovit vitamin complex that contributes to production of high-quality seed material. $[8,11,15]$.

The composition of the nutrient medium affects the organogenesis and the multiplication factor of the studied potato varieties. To improve the technology of reproduction of the source material, we studied selection of the optimal concentration of the Pikovit vitamin complex, which has a positive effect on production of high-quality seed material $[10,12]$.

\section{Methods}

The work on study of the Pikovit vitamin complex was carried out in the laboratory for clonal micropropagation of plants of the Velikie Luki State Agricultural Academy in 2020, through laboratory experiments. The studies were carried out according to the methods for carrying out work with tissue culture and clonal micropropagation of potatoes, methods for potatoes developed by the All-Russian Research Institute of Potato Farming and the Department of Biotechnology of the Moscow Agricultural Academy.

The aim of this paper is to study the most effective concentrations of nutrient media in vitro to increase the multiplication factor of potato test tube material.

The experiments were carried out in four repetitions (20 plants each) according to the method of working with tissue culture. During the study, at different stages of development, the number of roots and their length, the number of internodes, and the height of plants were measured.

The object of the study: domestic potato varieties:

Liga is an early ripening variety. Plant is low to medium height, intermediate type, semi-erect. Medium to large leaf, intermediate type, dark green. The waviness of the edge is strong. Corolla is red-violet. Marketable yield is 211-354 c/ha. The tuber is oblong-oval with small eyes. The peel is smooth, yellow. The pulp is light yellow. The mass of the marketable tuber is $92-125 \mathrm{~g}$. Starch content is $11.8-16.4 \%$. The taste is good. Marketability is $83-94 \%$. Keeping quality is $93 \%$. It is resistant to the causative agent of potato cancer and golden potato cyst nematode. According to the All-Russian Research Institute of Phytopathology, it is moderately susceptible in terms of tops and tubers to the causative agent of late blight.

Aurora is a mid-season variety. Tubers are oval-oblong in shape, with a light smooth 
skin. The eyes of the variety are small, there are red spots around the eyes. The pulp of the tuber has a white-cream color, contains from 14 to $21 \%$ of starch. Tubers of this variety are well stored, they can even last until next fall. The potato tops grow tall and erect. The leaves are bright green, the flowers are purple-red. The flowers are large in size. 380550 centners of the crop are harvested from one hectare of potatoes.

Gusar is a mid-season variety. Starch content is $15-17 \%$. Taste is good. Creamy pulp does not darken. It is resistant to cancer, late blight, scab, viruses. It is drought-resistant, keeping quality is very good. Tubers have a deep dormant period.

Pikovit vitamin complex [2].

Micropropagation optimization scheme:

1. MS + Control;

2. MS + Pikovit $-0.5 \mathrm{mg} / \mathrm{l}$;

3. MS + Pikovit - $1.0 \mathrm{mg} / \mathrm{l}$;

4. MS + Pikovit - $1.5 \mathrm{mg} / \mathrm{l}$

Description of the Pikovit vitamin used in the study:

Pikovit - Composition of tablets Pikovit - contents per 1 tablet: Vitamin A (retinol palmitate) - 180 micrograms (327 IU) Vitamin $\mathrm{D}_{3}$ (cholecalciferol) - 2.2 micrograms (88 $\mathrm{IU}$ ), vitamin $\mathrm{B}_{2}$ (riboflavin sodium phosphate) - $0.3 \mathrm{mg}$, Vitamin $\mathrm{B}_{1}$ (thiamine hydrochloride) $-0.25 \mathrm{mg}$, Vitamin $\mathrm{B}_{6}$ (pyridoxine hydrochloride) $-0.3 \mathrm{mg}$, Vitamin $\mathrm{B}_{12}$ (cyanocobalamin) - $0.2 \mathrm{mg}$, Vitamin C (ascorbic acid) - $10 \mathrm{mg}$, Vitamin PP (nicotinamide) - $3 \mathrm{mg}$, Vitamin $\mathrm{B}_{5}$ (pantothenic acid) $-1.2 \mathrm{mg}$, Vitamin $\mathrm{B}_{9}$ (folic acid) -4 micrograms, Calcium - $12.5 \mathrm{mg}$, Phosphorus - $10 \mathrm{mg}$

The vitamins we study are active substances that play an essential role in tissue culture. In the process of growth, plants synthesize the amount of vitamins they need. However, studies show that when vitamins are added to the nutrient medium, tissue growth improves. Presence or absence of vitamins in the nutrient medium has a significant effect on the morphogenesis of test-tube plants [3, 10, 17].

Presence or absence of vitamins in the nutrient medium has a significant effect on the morphogenesis of test-tube plants. So, for example, vitamin B6 is the most important in maintaining the balance of potassium and sodium in the body and is a necessary substance for the complete metabolism of proteins, carbohydrates and fats.

Ascorbic acid in the plant organism is involved in the transport of hydrogen. Vitamin C increases the frost resistance of plants. The vitamin B6 molecule contains nitrogen, the main element of the mineral nutrition of plants, an increase in its concentration in the nutrient medium leads to formation of a powerful assimilatory stem-leaf apparatus. The level of nitrogen nutrition determines the size and intensity of the synthesis of protein and other nitrogenous organic compounds in plants and, consequently, growth processes [14].

\section{Results}

As a result of the studies carried out on the study of the Pikovit vitamin complex, we found that in the early ripe potato variety Liga, positive results in the number of internodes and plant height on the seventh day of cultivation were obtained on a nutrient medium with addition of the vitamin complex at the concentration of $1.5 \mathrm{mg} / \mathrm{l}$ and, accordingly were equal to $1.7 \mathrm{pcs}$ and $19.9 \mathrm{~mm}$ (Table 1).

On the 14th day of passage, the largest number of internodes $3.5 \mathrm{pcs}$ were formed on a nutrient medium with addition of vitamins at the concentration of $0.5 \mathrm{mg} / \mathrm{l}$, and higher plants were recorded in the variant with MS + Pikovit $1.5 \mathrm{mg} / \mathrm{l}$ and was equal to $50.1 \mathrm{~mm}$. On the 21st day of cultivation, the morphogenesis of plants as a whole was positively influenced by the nutrient medium with addition of vitamins at the concentration of $1.5 \mathrm{mg} / \mathrm{l}$, which in terms of the number of internodes exceeded the standard by 0.1 pcs and 
in terms of plant height by $19.4 \mathrm{~mm}$. The smallest microplants of the Liga cultivar were obtained on a medium supplemented with vitamins at the concentration of $1.0 \mathrm{mg} / \mathrm{l}$.

When studying the Aurora variety on the seventh day of observations, a positive result in the number of internodes was noted on the standard MS medium $-2.0 \mathrm{pcs}$, and in height $-23.4 \mathrm{~mm}$ on the MS + Pikovit $0.5 \mathrm{mg} / \mathrm{l}$ medium.

Table 1. The dynamics of the development of the morphogenesis process in potato microplants, depending on modification of the nutrient medium with addition of the Pikovit vitamin complex.

\begin{tabular}{|c|c|c|c|c|c|c|c|c|c|}
\hline \multirow[t]{3}{*}{ Variety } & \multirow[t]{3}{*}{$\begin{array}{l}\text { Modified } \\
\text { culture } \\
\text { medium }\end{array}$} & $\begin{array}{c}\text { Nu } \\
\text { mbe } \\
\text { r of } \\
\text { inter } \\
\text { node } \\
\text { s, } \\
\text { pes. }\end{array}$ & \multirow[t]{3}{*}{$\begin{array}{l}\text { Plant } \\
\text { height } \\
, \mathbf{m m}\end{array}$} & $\begin{array}{l}\text { Nu } \\
\text { mbe } \\
\text { r of } \\
\text { inte } \\
\text { rno } \\
\text { des, } \\
\text { pcs. }\end{array}$ & $\begin{array}{l}\text { Plant } \\
\text { height, } \\
\text { mm }\end{array}$ & \multicolumn{2}{|c|}{$\begin{array}{c}\text { Number of } \\
\text { internodes, } \\
\text { pcs. }\end{array}$} & \multicolumn{2}{|c|}{$\begin{array}{c}\text { Plant height, } \\
\text { mm }\end{array}$} \\
\hline & & \multirow{2}{*}{ on day 7} & & \multirow{2}{*}{\multicolumn{2}{|c|}{ on day 14}} & \multicolumn{4}{|c|}{ on day 21} \\
\hline & & & & & & & $\pm \mathbf{S t}$ & & $\pm \mathbf{S t}$ \\
\hline \multirow{4}{*}{ Liga } & MS & 1.2 & 19.1 & 3.3 & 47.8 & 4.6 & - & 65.4 & - \\
\hline & $\begin{array}{l}\text { MS + } \\
\text { Pikovit } \\
0.5 \mathrm{mg} / 1\end{array}$ & 1.6 & 18.2 & 3.5 & 48.1 & 4.0 & -0.6 & 65.7 & +0.3 \\
\hline & $\begin{array}{l}\mathrm{MS}+ \\
\text { Pikovit } 1.0 \\
\mathrm{mg} / 1\end{array}$ & 1.5 & 18.0 & 3.0 & 47.7 & 4.2 & -0.4 & 53.5 & -11.9 \\
\hline & $\begin{array}{l}\text { MS + } \\
\text { Pikovit } \\
1.5 \mathrm{mg} / 1\end{array}$ & 1.7 & 20.3 & 3.4 & 50.1 & 4.7 & +0.1 & 84.8 & +19.4 \\
\hline \multirow{4}{*}{ Aurora } & MS & 2.0 & 19.9 & 4.3 & 28.4 & 6.2 & - & 68.9 & - \\
\hline & $\begin{array}{l}\text { MS + } \\
\text { Pikovit } \\
0.5 \mathrm{mg} / \mathrm{l} \\
\end{array}$ & 1.8 & 23.4 & 4.0 & 35.5 & 6.5 & +0.3 & 69.5 & +0.6 \\
\hline & $\begin{array}{l}\text { MS + } \\
\text { Pikovit } 1.0 \\
\text { mg/l }\end{array}$ & 1.2 & 16.8 & 4.5 & 41.8 & 6.6 & +0.4 & 72.9 & +4.0 \\
\hline & $\begin{array}{l}\text { MS + } \\
\text { Pikovit } \\
1.5 \mathrm{mg} / 1 \\
\end{array}$ & 1.0 & 15.3 & 3.2 & 38.9 & 5.7 & -0.5 & 63.2 & -5.7 \\
\hline \multirow{4}{*}{ Gusar } & MS & 1.9 & 18.1 & 3.6 & 48.5 & 5.2 & & 94.2 & \\
\hline & $\begin{array}{l}\text { MS + } \\
\text { Pikovit } \\
0.5 \mathrm{mg} / 1\end{array}$ & 1.6 & 17.9 & 2.7 & 39.3 & 4.7 & -0.5 & 81.4 & -12.8 \\
\hline & $\begin{array}{l}\text { MS + } \\
\text { Pikovit } 1.0 \\
\text { mg/l }\end{array}$ & 1.8 & 18.0 & 3.7 & 54.4 & 5.8 & +0.6 & 106.1 & +11.9 \\
\hline & $\begin{array}{l}\text { MS + } \\
\text { Pikovit } \\
1.5 \mathrm{mg} / 1\end{array}$ & 1.4 & 17.6 & 3.9 & 48.7 & 5.0 & -0.2 & 96.2 & +2.0 \\
\hline
\end{tabular}

On 14th, 21th day of cultivation in this variety, the nutrient medium with addition of vitamins at the concentration of $1.0 \mathrm{mg} / \mathrm{l}$ had a positive effect on the number of internodes and the height of microplants, which, respectively, equaled to $-4.5 \mathrm{pcs},-6.6 \mathrm{pcs}$, and $41.8 \mathrm{~mm}, 72.9 \mathrm{~mm}$, and which exceeded the standard by $0.4 \mathrm{pcs}$ and $4.0 \mathrm{~mm}$, respectively. The minimum results were noted on the 21 st day on a nutrient medium with addition of the Pikovit complex of vitamins at the concentration of $1.5 \mathrm{mg} / \mathrm{l}$, the number of internodes was 
$5.7 \mathrm{pcs}$, and the plant height was $63.2 \mathrm{~mm}$, which is less than the standard by $0.5 \mathrm{pcs}$ and $5.7 \mathrm{~mm}$, respectively.

The mid-ripening variety Gusar has a greater number of internodes $-2.0 \mathrm{pcs}$ and the height of $18.1 \mathrm{~mm}$ on the 7th day of growth formed on MS medium. On the 14th and 21st days of cultivation, these indicators were noted in the MS medium + Pikovit $1.0 \mathrm{mg} / \mathrm{l}$. In terms of the number of internodes, the standard was exceeded by $0.6 \mathrm{pcs}$, and in terms of plant height, this value was $11.9 \mathrm{~mm}$. Weaker and stunted microplants were noted on the studied nutrient medium with addition of the Pikovit vitamin complex $0.5 \mathrm{mg} / \mathrm{l}$, which is 4.7 pcs and $81.4 \mathrm{~mm}$, which is $0.5 \mathrm{pcs}$ and $12.8 \mathrm{~mm}$ below the standard value, respectively.

In clonal micropropagation for the further development of plants in vivo is the process of rhizogenesis. The main indicator of rhizogenesis for plants in vitro is the number of roots and their length. The root system plays an important role in development of plants as a whole; vitamins are given the first place here, since they stimulate development of rhizogenesis in potato plants. Thanks to a well-formed root system, plants that are transplanted into in vivo conditions from in vitro conditions tolerate adaptation better, root better, since they fully consume moisture and nutrients from the soil. Thanks to this, microplants form a healthy bush, and subsequently a healthy, high-quality, healthy seed material of potatoes with a high yield. [6].

Based on the results of the work done, it can be seen from Table 2 that the largest number of roots on the seventh day of cultivation in Liga variety was formed on the standard nutrient medium MS $-2.8 \mathrm{pcs}$, and their maximum length was noted on the medium MS + Pikovit at the concentration of $1.5 \mathrm{mg} / 1-18.2 \mathrm{~mm}$. On the 14th day of counting, the studied medium with the concentration of the Pikovit vitamin complex of $1.0 \mathrm{mg} / \mathrm{l}$ had a positive effect on the root system, and was equal in terms of the number of roots, this result was $-4.9 \mathrm{pcs}$, and in terms of the length of the roots $-96.1 \mathrm{~mm}$, respectively. On the last day of cultivation of potato microplants, the best result was obtained on the MS + Pikovit $1.5 \mathrm{mg} / \mathrm{l}$ medium, by the number of roots $-8.2 \mathrm{pcs}$ and by the length of roots $-117.3 \mathrm{~mm}$, which exceeded the standard by 1.1 pcs by the number of roots, and along the length of the roots by $14.1 \mathrm{~mm}$.

Table 2. Development of the root system of potato microplants, depending on modification of the nutrient medium with addition of the Pikovit vitamin complex.

\begin{tabular}{|c|c|c|c|c|c|c|c|c|c|}
\hline \multirow[t]{3}{*}{ Variety } & \multirow[t]{3}{*}{$\begin{array}{l}\text { Modified } \\
\text { culture } \\
\text { medium }\end{array}$} & $\begin{array}{c}\text { Num } \\
\text { ber } \\
\text { of } \\
\text { roots, } \\
\text { pcs. }\end{array}$ & $\begin{array}{c}\text { Len } \\
\text { gth } \\
\text { of } \\
\text { roo } \\
\text { ts, } \\
\text { mm }\end{array}$ & $\begin{array}{c}\text { Nu } \\
\text { mb } \\
\text { er } \\
\text { of } \\
\text { roo } \\
\text { ts, } \\
\text { pcs. }\end{array}$ & $\begin{array}{l}\text { Leng } \\
\text { th of } \\
\text { roots } \\
\text {, mm }\end{array}$ & \multicolumn{2}{|c|}{$\begin{array}{l}\text { Number of } \\
\text { roots, pes. }\end{array}$} & \multicolumn{2}{|c|}{$\begin{array}{l}\text { Length of } \\
\text { roots, } \mathrm{mm}\end{array}$} \\
\hline & & \multirow{2}{*}{\multicolumn{2}{|c|}{ on day 7}} & \multirow{2}{*}{\multicolumn{2}{|c|}{ on day 14}} & \multicolumn{4}{|c|}{ on day 21} \\
\hline & & & & & & & $\pm \mathbf{S t}$ & & $\pm \mathbf{S t}$ \\
\hline \multirow{4}{*}{ Liga } & MS & 2.8 & 16.2 & 4.2 & 84.5 & 7.1 & - & $\begin{array}{c}103 . \\
2\end{array}$ & - \\
\hline & $\begin{array}{c}\text { MS + Pikovit } \\
0.5 \mathrm{mg} / \mathrm{l}\end{array}$ & 0.4 & 5.6 & 4.0 & 73.6 & 6.3 & -0.8 & 98.7 & -4.5 \\
\hline & $\begin{array}{c}\text { MS + Pikovit } \\
1.0 \mathrm{mg} / 1 \\
\end{array}$ & 2.1 & 13.3 & 4.9 & 96.1 & 8.0 & +0.9 & $\begin{array}{c}102 . \\
1\end{array}$ & -1.1 \\
\hline & $\begin{array}{c}\text { MS + Pikovit } \\
1.5 \mathrm{mg} / \mathrm{l}\end{array}$ & 2.7 & 18.2 & 4.5 & 90.4 & 8.2 & +1.1 & $\begin{array}{c}117 . \\
3\end{array}$ & +14.1 \\
\hline \multirow[b]{2}{*}{ Aurora } & MS & 1.4 & 13.1 & 3.5 & 48.7 & 3.5 & - & 95.2 & - \\
\hline & $\begin{array}{c}\mathrm{MS}+\text { Pikovit } \\
0.5 \mathrm{mg} / \mathrm{l}\end{array}$ & 1.0 & 11.3 & 3.9 & 57.9 & 4.2 & +0.7 & 87.5 & -7.7 \\
\hline
\end{tabular}




\begin{tabular}{|c|c|c|c|c|c|c|c|c|c|}
\hline \multirow{7}{*}{} & $\begin{array}{c}\text { MS + Pikovit } \\
1.0 \mathrm{mg} / \mathrm{l}\end{array}$ & 1.9 & 17.5 & 4.4 & 67.3 & 5.2 & +1.7 & $\begin{array}{c}115 . \\
6\end{array}$ & +20.4 \\
\cline { 2 - 9 } & $\begin{array}{c}\text { MS + Pikovit } \\
1.5 \mathrm{mg} / \mathrm{l}\end{array}$ & 2.3 & 20.6 & 4.2 & 60.6 & 4.9 & +1.4 & $\begin{array}{c}103 . \\
4\end{array}$ & +8.2 \\
\hline \multirow{5}{*}{ Gusar } & $\mathrm{MS}$ & 2.3 & 16.5 & 3.6 & 82.1 & 4.3 & - & $\begin{array}{c}100 . \\
4\end{array}$ & - \\
\cline { 2 - 9 } & $\begin{array}{c}\text { MS + Pikovit } \\
0.5 \mathrm{mg} / \mathrm{l}\end{array}$ & 2.0 & 10.6 & 2.9 & 77.5 & 3.8 & -0.5 & 89.2 & -11.2 \\
\cline { 2 - 9 } & $\begin{array}{c}\text { MS + Pikovit } \\
1.0 \mathrm{mg} / \mathrm{l}\end{array}$ & 1.8 & 11.8 & 3.9 & 80.2 & 5.5 & +1.2 & $\begin{array}{c}118 . \\
6\end{array}$ & +18.2 \\
\cline { 2 - 9 } & $\begin{array}{c}\text { MS + Pikovit } \\
1.5 \mathrm{mg} / \mathrm{l}\end{array}$ & 1.5 & 13.3 & 3.0 & 88.1 & 5.0 & +0.7 & $\begin{array}{c}116 . \\
7\end{array}$ & +16.3 \\
\hline
\end{tabular}

When studying the Aurora variety, the nutrient medium with addition of vitamin at the concentration of $1.5 \mathrm{mg} / \mathrm{l}$ had the positive effect on the root system of microplants as a whole, 2.3 pcs of roots were formed, and their length was $18.2 \mathrm{~mm}$. On the following days of cultivation, these are 14th and 21th days, more powerful root system was formed on MS + Pikovit $1.0 \mathrm{mg} / \mathrm{l}$ medium. That exceeded the standard on the twenty-first day - by $1.7 \mathrm{pcs}$ by the number of roots and - by $20.4 \mathrm{~mm}$ along the length of the roots, respectively.

In the Gusar variety, the maximum in the number and length of roots on the 7 th day of passage was noted on the standard MS nutrient medium - 2.3 pcs and $16.5 \mathrm{~mm}$, respectively. On the 14th day, a larger number of roots $-3.9 \mathrm{pcs}$, were obtained on MS + Pikovit $1.0 \mathrm{mg} / \mathrm{l}$ medium, and a larger length $-88.1 \mathrm{~mm}$ on MS + Pikovit $1.5 \mathrm{mg} / \mathrm{l} \mathrm{medium}$ was observed. The positive effect was made by the nutrient medium MS + Pikovit $1.0 \mathrm{mg} / \mathrm{l}$ on the growth and development of roots on the 21 st day of passage, and exceeded the standard values for the number of roots - by $1.2 \mathrm{pcs}$, along the length of the roots - by $18.2 \mathrm{~mm}$.

\section{Discussion}

For the first time in the conditions of the North-West zone of Russia, studies of the drug Pikovit were carried out in concentrations from $0.5-1.5 \mathrm{mg} / \mathrm{l}$. The process and methods of clonal micropropagation of potato varieties with use of new preparations has been improved, the selection of nutrient media at all stages of cultivation has been carried out. Improvement of processes is in demand and economically profitable, this has led to a reduction in material, labor and energy costs of production.

\section{Conclusion}

Based on the results of the work done, the following conclusion can be made that vitamins play an important role at the last stage of micropropagation of potato plants immediately before planting in vivo conditions. A more powerful well-formed root system develops, which favorably affects survival of microplants during planting.

\section{Conclusions}

1. Use of the Pikovit vitamin complex in a nutrient medium has a positive effect on the ontogenesis of potato microplants in general.

2. The study of the effect of vitamins on the test tube material of potatoes favorably influenced the formation of internodes - the plant reproduction coefficient. Early potato variety Liga microplants with cultivation on the nutrient medium using the most optimal concentration of the Pikovit vitamin complex $-1.5 \mathrm{mg} / \mathrm{l}$ were obtained. It was wellformed by morphogenesis and developed root system. For other studied varieties of the 
mid-season group of potato varieties Aurora and Gusar, the optimal nutrient medium was addition of the Pikovit vitamin complex at the concentration of $1.0 \mathrm{mg} / \mathrm{l}$.

\section{References}

1. S.I. Artyukhova, I.V. Kirgizova, Omsk Scientific Bulletin, 2 (2014)

2. K.Yu. Guseva, I. D. Borodulina, E.P. Myakisheva, O.K. Tavartkiladze, Izvestiya AltSU, 2 (2013)

3. E.V. Zhuravleva, Achievements of science and technology in the agro-industrial complex, 26, 12 (2015)

4. E.A. Kalashnikov (Study guide, publishing house RSAU-Moscow Agricultural Academy, 2016)

5. N.V. Lebedeva, Yu.N. Fedorova, Bulletin of the Russian State Agrarian Correspondence University (2014)

6. Yu.N. Fedorova (Atlantis Press, 2018)

7. E. A. Simakov (Improvement of potato cultivation technology, Ministry of Agriculture and Food of the Russian Federation, 2000)

8. A.M. Malko, B.V. Anisimova (FGBU "Rosselkhoztsentr", FGBNU VNIIKH, 2017)

9. Yu.N. Fedorova (Materials of the International Congress "Biotechnology: State and Development Prospects", 2019)

10. B.C. Shevelukha (Publishing house ITRK, 2016)

11. V. A. Barker Allen, Field Crops Research, 212 (2017)

12. B. Burlingame, Journal of Food Composition and Analysis, 22, 6 (2009)

13. Yu. F. Drygin, Potato Production and Innovative Technologies (2007)

14. M. Fufa, Advances in Crop Science and Technology Fufa and Diro, Adv. Crop. Sci. Tech. (2014)

15. Y. Li, Field Crops Research, 269 (2021)

16. Z. Sheng-Peng, Acta Ecologica Sinica, 30, 4 (2010)

17. K. L. Wong, Plant Cell, 14 (2002) 